\title{
4. 腎障害とミネラロコルチコイド
}

\author{
長 瀬 美 樹*
}

\section{1 . アルドステロンは糸球体足細胞障害を介して蛋白尿を 惹起する}

アルドステロンは従来，腎臓の遠位ネフロンに作用して 電解質・循環血液量, 血圧調節を司るホルモンと考えられ てきた，ところが近年，アルドステロン研究における大き なパラダイムシフトが生じ, 心腎血管系臓器障害のメディ エーターとしてのアルドステロンの役割がクローズアップ されている。腎臓ではアルドステロンは蛋白尿，糸球体硬 化，腎線維化などを惹起する。

我々は，アルドステロン慢性投与ラットに扔ける蛋白尿 のメカニズムとして, 糸球体に扔ける蛋白濾過バリアとし て重要な糸球体足細胞の障害につき検討した ${ }^{11}$. 本ラット は激しい蛋白尿を生じ, このとき正常足細胞のマーカーで あるネフリン，ポドシンの発現は蛋白尿発症早期より激減 しており，逆に足細胞障害マーカーであるデスミンの発現 は増強し, 電顕所見からも足突起の消失など足細胞障害の 存在が示された。足細胞にはアルドステロンの受容体であ る鉱質コルチコイド受容体 (MR) が発現しており,アルド ステロンによる蛋白尿増加の少なくとも一部は足細胞に対 する直接障害作用による可能性が考えられた.

\section{2.メタボリックシンドロームモデル動物の腎障害と内因 性アルドステロン}

次に我々は, メタボリックシンドロームモデルとして SHR/NDmcr-cp (SHR 肥満ラット) を用いて, 内因性アル ドステロンと足細胞障害, 蛋白尿について検討した ${ }^{2}$ 。こ のラットは, 自然発症高血圧ラット（SHR）にレプチン受 容体遺伝子異常が導入されたもので, メタボリックシンド ロームの構成要素を併せもっている.

SHR 肥満ラットでは蛋白尿が早期より増加しており, これと関連して足細胞障害がみられた。また SHR 肥満 ラットの血中アルドステロン濃度を測定したところ, 非肥 満 SHR に比し有意に上昇しており，血中アルドステロン 濃度と蛋白尿の間には正の相関がみられた。アルドステロ ンのエフェクターである Sgk1 の糸球体，腎臓における発 現もSHR 肥満ラットで有意に光進していた。 そして SHR 肥満ラットに MR 拮抗薬エプレレノンを投与したところ,

\footnotetext{
* 東京大学大学院医学系研究科腎臓・ 内分泌内科慢性腎臟病 (CKD) 学講座

干 113-8655 東京都文京区本郷 7-3-1
}

足細胞障害，尿蛋白はともに著明に抑制された。このこと から, 本モデルではアルドステロン過剩が見られ, 腎臓や糸 球体におけるアルドステロン作用の充進が足細胞障害, 蛋 白尿などの病態を引き起こしているものと考えられた。 ア ルドステロン上昇のメカニズムとしては, 本稿では詳しく 述べないが, 我々は肥満脂肪細胞より分泌されるアルドス テロン分泌刺激物質の関与に注目し, 検討を行っている.

\section{3.メタボリックシンドロームにおける食塩の害とアルド \\ ステロン}

臨床的に, 肥満者では食塩過剩摂取により臟器障害が悪 化しやすいことが知られている. SHR 肥満ラットを高食 塩食で飼育した場合にも, 足細胞障害, 蛋白尿は著しく増 悪した ${ }^{3)}$. 興味深いことに食塩による足細胞障害, 蛋白尿 の悪化はMR 拮抗薬により完全に回復した。このことは食 塩による腎障害の病態にアルドステロン/MR シグナリン グが極めて重要な役割を担う可能性を強く示唆する。実際 高食塩食により腎臟における MR シグナリングが元進し， 確かに食塩が MR 活性を増強するものと考えられた，その 一因として，レニンーアンジオテンシン系によって制御さ れるアルドステロン産生は食塩により抑制されるが，脂肪 由来因子によるアルドステロン産生は食塩により抑制され ず，食塩摂取量に比しアルドステロンが不適切に高いこと が関与している可能性が考えられる.

\section{MR 活性化の新たなメカニズム}

ここまでアルドステロン值が高いモデルにおける足細胞 障害と MR 拮抗薬の保護効果をみてきたが, MR 拮抗薬が 有効であるのは必ずしもアルドステロン高值例に限ったこ とでないことは臨床的にも動物モデルでも知られている. すなわち，血中アルドステロン濃度が高くなくても標的臟 器に抢ける MR シグナリングの光進がみられ，MR 拮抗薬 が著効を示すこともあるのである゙).

アルドステロン非依存性の MR 活性化のメカニズムに ついては従来ほとんど解明されていなかったが，MRは核 内受容体で, リガンドが結合すると核へ移行し, 標的遺伝 子のプロモーターのホルモン応答配列に結合し, 標的遺伝 子発現を引き起こす，という見地から考えると，血中リガ ンドレベルの変化以外にもさまざまな要因によって活性が 制御されている可能性がある。実際研究が進んでいる他の ステロイド受容体に関しては種々の細胞内シグナル因子が 
活性化因子として働くことが示されている. 我々は, 低分 子量 $\mathrm{G}$ 蛋白 Rac1による MR 活性化機構を見いだした5).

まず， Rac1 が MR 活性化を引き起こすか否か, in vitro の系で検討を行った. HEK293 細胞に恒常活性型 Rac1 （CA-Rac1）を遺伝子導入し, MR 活性化の指標として, MR の核移行を GFP（緑色蛍光蛋白質）標識 MR の導入に より，MR 依存性転写の促進をルシフェラーゼアッセイに より評価した，培養細胞に GFP で標識した MR をトラン スフェクションさせると，アルドステロンがない状態では MR は扔もに細胞質に局在し，アルドステロンを添加する と核への移行が観察される。この際, 恒常活性型 Rac1 を 遺伝子導入しておくと MR の核移行が起こりやすくなる ことが示された. また, MR 転写活性をルシフェラーゼアッ セイにて評価すると，アルドステロン添加により MR 転写 活性は上昇するが，恒常活性型 Rac1 を遺伝子導入してお くとこの反応が増強することがわかった，すなわち，活性 型 Rac1 により MR 活性化が生じることが in vitro の系に おいて示された。

そこで次に『Rac1による MR 活性化』が in vivoでの腎 障害のメカニズムにも関与しうるか否か, 腎臓でRac1の 活性化が生じる Rho GDI $\alpha$ KO マウスを用いて検討した。 Rho GDI は不活性型の Rho GTPase に結合してその不活 性状態の維持に関与すると考えられているが, このモデル では腎臟特異的に Rac1 の活性化が生じていた。このマウ スでは生後徐々に腎障害が進行し, 12 週齢では著明なアル ブミン尿, 足細胞障害, 糸球体硬化を呈した。そして Rac 阻害薬を投与すると, このようにアルブミン尿, 腎障害は 改善した．アルドステロン・MR 系を調べてみると, Rac1 活性化マウスでは血中アルドステロン濃度, 血圧はいずれ も野生型マウスと同等であったが, 腎臓に打ける MR 発 現, シグナル下流の Sgk1 発現は増加しており, アルドス テロン非依存的に MR activation が生じていることが示唆 された。ささらに, Rac 阻害薬を投与すると, 腎臟において 克進していた MR 活性化が抑えられること，このマウスに MR 拮抗薬を投与するとアルブミン尿, 腎病理所見が改善 することから, Rac1による MR 活性化が本モデルの腎障 害の本体であると考えられた。

この Rac1 過剩モデルは人為的なモデルであるが, 一般 的な腎障害モデルとして, 食塩感受性高血圧モデルやメ夕 ボリックシンドロームに伴う腎障害などにおいても, Rac1 の過剩活性化が病態に寄与していることが示されている.

\section{5.むすび 〜MR 活性制御をターゲットとした腎障害の \\ 新たな治療法の探索 (Fig.)}

以上，腎障害とアルドステロン/MR 系の過剩活性化に ついて, とくにメタボリックシンドロームにおける役割や, 慢性腎藏病の新たな治療薬としての Rac 阻害薬の可能性 を示した.アルドステロンが高い病態においては糸球体足 細胞障害, 蛋白濾過バリアの破壞により蛋白尿が引き起こ される。アルドステロンが高くない場合にも，たとえば

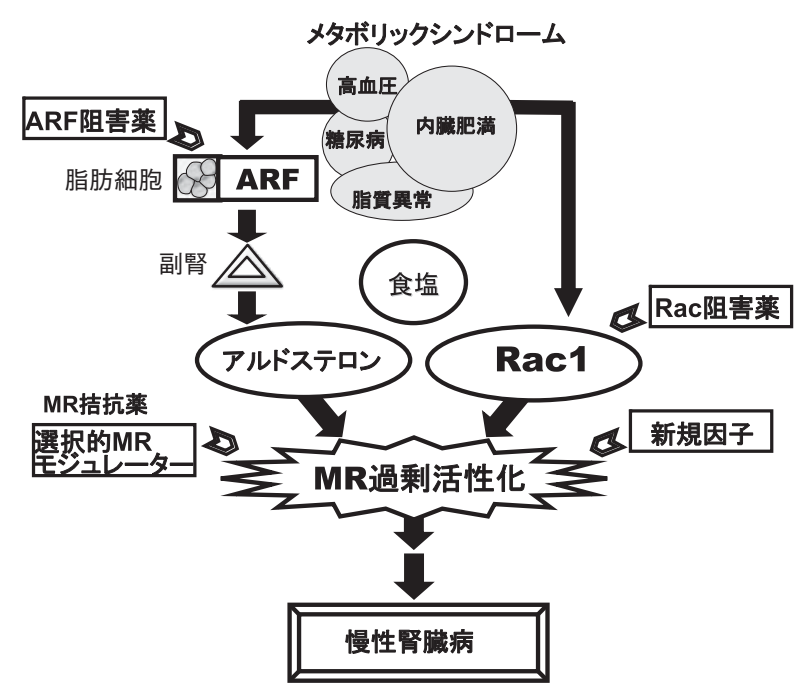

Fig. メタボリックシンドロームの腎障害と, MR 活性制御を ターゲットとした新たな治療法の探索

メタボリックシンドロームに伴う腎障害の発症メカニズムとして，ア ルドステロン依存性・非依存性機序によるミネラロコルチコイド受容 体（MR）過剩活性化が重要な役割を果たしている。しかしながら, MR 拮抗薬は多くの慢性腎臟病患者では使用できず, MR 活性制御を ターゲットとした新たな腎臟病治療薬として, Rac 阻害薬, 脂肪細胞 由来アルドステロン分泌促進物質 (ARF) の阻害薬, 選択的 MR モジュ レーターなどの創製に期待がもたれる。

Rac1 の活性化によりアルドステロンに対する MR の感受 性が高まり，蛋白尿を生じうる。いずれの場合にも MR 拮 抗薬が有用である. しかしながら, 現状では高 K 血症の懸 念により多くの慢性腎臓病患者（アルブミン尿を伴う糖尿 病患者, 中等度以上の腎機能障害患者) で MR 拮抗薬は使 用禁忌となっている.今後, MR 活性を制御するような新た な腎保護薬として, Rac 阻害薬, 高 $\mathrm{K}$ 血症を来たさないよう な選択的 MR モジュレーターの創製に期待がもたれる.

\section{文献}

1) Shibata S, Nagase M, Yoshida S, Kawachi H, Fujita T. Podocyte as the target for aldosterone : roles of oxidative stress and Sgk1. Hypertension. $2007 ; 49(2): 355-64$.

2) Nagase M, Yoshida S, Shibata S, Nagase T, Gotoda T, Ando K, et al. Enhanced aldosterone signaling in the early nephropathy of rats with metabolic syndrome: possible contribution of fatderived factors. J Am Soc Nephrol. 2006 ; 17 (12) : 3438-46.

3) Nagase M, Matsui H, Shibata S, Gotoda T, Fujita T. Salt-induced nephropathy in obese spontaneously hypertensive rats via paradoxical activation of the mineralocorticoid receptor : role of oxidative stress. Hypertension. $2007 ; 50(5): 877-83$.

4) Nagase M, Shibata S, Yoshida S, Nagase T, Gotoda T, Fujita T. Podocyte injury underlies the glomerulopathy of Dahl salthypertensive rats and is reversed by aldosterone blocker. Hypertension. $2006 ;$ 47 (6) : 1084-93.

5) Shibata S, Nagase M, Yoshida S, Kawarazaki W, Kurihara H, Tanaka H, et al. Modification of mineralocorticoid receptor function by Rac1 GTPase : implication in proteinuric kidney disease. Nat Med. $2008 ; 14(12): 1370-6$. 